\title{
Center - Periphery Urban Territorial Dynamics: The Case of Durrës Municipality- Albania
}

\author{
Prof. Assoc. Dr. Bilal Draçi \\ University of Tirana, Faculty of History and Philology, Geography Department \\ Email: bilal_draci@yahoo.it
}

Msc. Dritan Çaro

Polytechnic University of Tirana. Faculty of Architecture and Urban Planning. The Department of City Planning.

Email:dritancaro@yahoo.com

Prof. Assoc. Dr. Pal Nikolli

University of Tirana, Faculty of History and Philology, Geography Department

Email: palnikolli@yahoo.com

\section{Doi:10.5901/mjss.2014.v5n9p552}

\section{Abstract}

Model center - periphery constitutes an efficient instrument and method to analyze geographical and territorial estimates of current developments. Model measures and evaluates developments imbalances or balance, sustainable development, directions, structural changes specific territorial space, in this case urban, exchanges and interaction interdependence, integration processes, borders etc. Its measuring is done by some quantitative statistical and qualitative indicators such as density and distribution; intensity (Davis index, indicator of central placement; indicator central business etc.); tendency of directions etc. Their assessment is based on physical, historical and monumental cultural assets; demographic and socio economic development, positioning and their respective typology: morphological, functional and territorial. The assessments show that: the center and the periphery as two spatial categories specific to a single spatial system has clear expression in the urban territory of the municipality of Durres. This is expressed with visible changes of qualitative and quantitative indicators morphological urban, urban population, urban functions and positioning of their alignment. In all the above elements are distinguished dynamic center and periphery, a transitional zone of mixed and consolidated urban - territorial terms, without any high dynamics and a further area outside urban agglomeration, so a space of interaction with the economy functions without homogenization urban planning. According to historical- territorial aspect, Durrës city has some similarity functions of a continuum of Balkan and European cities: the port and castle city in ancient time; trade - craftsman - port in the Middle Ages, with growth and extended functional - territorial urban, industrial - port and transport hub - tourist - administrative postindustrial city, through " de-industrialization " with manufacturer profile and domination city services (administrative - port - tourist trade and services industries. The work is carried out through the theoretical references, fieldwork, secondary and primary data statistics, drawings, maps, photos and synthesizing analysis estimates the geographical perspective.

Keywords: territorial model, center, periphery, transitional zone, urban center zone, agglomerative area, urban typology, urban functions, urban morphology, urban assets.

\section{Introduction}

A theoretical perspective of center-periphery model.

As a theoretical perspective of center-periphery model about territorial planning and arrangements, models, geographically, initially launched as a theoretical generalization of some territorial development practices, before the 30s years of the twentieth century. Geographers in voice as Kristaller; von Thynen; Löech and later from the 70s 60s years, Friedman, Rostow etc., generalized some practices of their spatial arrangement type models by presented as general theory contemporary arrangement of space. The model is based on evidence of large disparities in relation to spatial systems related to: physical and human assets, property and income, economic progress and growth between Centre and Periphery areas, using technology, urbanization and quality of life.. etc. Geographically spatial categories of the report center - periphery urban spaces studied in different system and the ranks: from global, continental, regional, national, local etc. 
Center and periphery constitutes two types of spatial a single spatial system that distinguished between them by three main features:

a. Structural changes. (Assets - the population - the economy and the development). In general in the center space observed concentration of some industries-depends from countries and type of industry, services, population. It has a developed infrastructure of higher income. On the outskirts-periphery prevails extensive agriculture activities, scattered population and scarce development infrastructure etc.

b. Not the same exchange relationships (people, goods and information). The center exports to the periphery the capital industrial products, services and contrary the periphery toward the center mostly sends: raw materials, manpower no or semi qualified.

c. Interdependent connection (functional). In the center focus of management decision-making power (government, administration, investment, etc.) and the development of the periphery depends on the decisions of the center and other differences smaller.

From the point Human Geography terms and in terms of long-term sustainable development the analysis of the center -periphery model is estimated as an instrument of territorial development approach in the study about: capacity, disparities, mechanisms, processes, issues, trends, and directions of their territorial perceptively development. More simply, aims to find mechanisms required spatial development processes and to find a consistent set of spatial developments. Periphery and Center geographically are often seen in isolation terms of studies, but they are organic parts of a space or territorial system - in this case urban. So far some research in Albania is focused more on the periphery than at other centers or intermediate zones.

\section{Methodology and Methods}

Geographical aspects of this urban-territorial dynamic, methodologically are focused from those: positioning and placement to physical-human territorial assets and urban dimensional reports, horizontal and vertical, demographic pressure and development; urban morphology as historical-territorial overview where typologies and developments that bear the stamp of the relevant times; urban population as demographic change from growth processes, structural changes in demographic, cultural, social and spatial; urban functions as functional development of urban change and, activities in the function of living etc.

\section{Territorial Center-Periphery Measurement and Evaluation}

For practical purposes of the study were developed several concepts and development indicators for territorial measurement and evaluation, where the main are as follows:

- Geo-urban centralization, which includes the dominance of urban functions; concentration in a certain (limited) space, within the city or an urban system or / and territorial; prevalence of some basic and qualitative function; coverage radius of up beyond their space; some aspects of the regulation and territorial infrastructure .... with the goal of maximum quality benefits by densification of population, high land values and advantages of the concentration of services, functional accessibility etc.

- $\quad$-Roof central business indicator (CBHI) which according to Anglo - Saxon literatures represents report of the total surface area of the land for the central business to all uses / spatial to the total area of the block land.

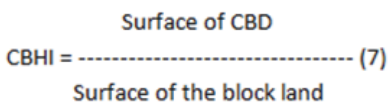

Greater Values than 1 was considered potentially high indicator. In the result of this indicator, Durres has a high index Davies, on 1 . The same, Tirana -Durres corridor concentrates nearly half of the "central functions" of Albanians.

- Urban-economic centralization (C) or Davis index, who is a European standard classification system activity as a comparison of urban population size, institutional status and economic centralization of urban areas.

This can be calculated according to the formula (5):

$\mathrm{Ci}=\Sigma j\left(\mathrm{Ni}{ }^{*}(1 / \mathrm{Nj})\right.$

$i=$ spatial unit

$j=$ economic activity (NACE service sector groups) 
$\mathrm{Nj}=$ total number of jobs in an area of activity $j$

$\mathrm{Ni}=$ number of jobs in the activity of the spatial unit $j$.

- as well as some other indicators: density ( ha ); distribution, position and distance , accessibility and connectivity..

The work was carried out on the basis of reference and quotation of: theoretical methodical and practical literature of the field as part of cameral work; primary data such as questionnaires and surveys, contacts and discussions with specialists, secondary data from relevant institutions in particular municipality office, county, INSTAT, Institute of Cultural Monuments, website, terminological dictionary of Human and Urban Geography and documentary fieldwork.

\section{Some Empirical Results and Discussion}

In synthesis, historical-territorial evolution of urban functional typology of Durres can be grouped as a:

a. "city", Port and Fortress (In Antiquity)

b. "city", trade - craft - port ( Middle Ages )

c. "city", with complex functions, urban surface growth ( up 2,800 ha, since 1987 up to now) and Urban functional extension to Industrial - Port - transport hub - tourist and administrative (industrial communist period)

d. "Transitive postindustrial city" (the share of industrial employment and industry under $25-30 \%$,) through the "De-industrialization" and domination of services city profile,

(Administrative - port trade and some tourism - industry services.. more that production..).

The term of "deindustrialization is used in the meaning of structural change of industries through the fall, alteration or destruction of that to existing manufacturing in favor of those manipulative and services, displacement of them beyond the urban periphery, creation of new industries to the regional, national and international market.

\section{Urban Population According to Some Synthetic Statistical Indicators}

In the nationwide context, Durres city after Tirana, bearded the major contribution in migratory processes, where immigration has risen up to $20 \%$. Its population has more than doubled up to 213,000 for about 20 year. The emigration / immigration ratio has been $1 / 2$ in favor of immigration, so namely population growth has dominated by immigration. Migration process has dominated the increase of population as well in relation to natural increase in the ratio, 1 with 9-87 , so with shrinking ratio in years.

What should have been recorded is the time average rates of growth which affect and characterizes urbanized processes. So after ' 90 years up to 2004-2006, average annual growth rate was $3 \%$. This, raised the emergent needs of the increasing demands for the large flats and dwellings as well as to filling gaps in the communist system.

After this period (2004-2006), the average annual growth rate has fallen since 1.7 to $1.5 \%$, with continued downward trend. This fall is related to decreasing weight of immigration to Durres up $0.3-0.2 \%$ and fertility decline. Consequently the developing requirements were oriented not only for housing more than community development for urban quality of life, social, economic and environmental. Urban density varies from 500 to 600 inhabitant/ha in the center up to 90 to 120 inhabit./ ha in suburbs areas. Projections by current trends, to 2020 year, are for up to 288,000 inhabitants.

By 2006, the people setting was mostly in the suburbs (in the swamp/wetlands area more than $60 \%$ of the total immigrated people ), and the rest were placed in the intensive residential touristic resorts area and Shkozet zone .

After 2006, the urban growth was dominated by the needs of urban and economic development in the suburbs and the centralization of functions mostly services in the centered etc. While periphery has known greater and fast extensive development, the urban center is characterized more by centralization in terms of service functions.

\section{Urban Morphology}

Processes, typology and territorial zoning bear the stamp of the time in Durres as well. Urban morphology reflects three cultural layers:

- Historical period before 1945 years, (with 1-2 storey buildings in the center and the area surrounding historic zone, with mixed architecture foreigner and national, mostly Italian.

- Communist period 1945-1990-(with standardization of 4-5 flats buildings, with clear functional separation).

- Capitalist period after 1990s (with mixes of buildings, hanging developments; lower private constructions, territorial congestion up overcrowding etc. 
The rhythm of apartment construction has been: up to 90 years $=3.8 \%, 1990-98,=5.7 \%$, from 98 to $2006,=>$ $13 \%$ and with additional urban area with 5000 ha.; after $2005=5.7$ to $4.5 \%$, so with decreasing tendencies.

Setting population by territorial zoning (horizontal) and height : > $45 \%$ are located in the periphery as informal dwellings (1-3 floors); 35-40 \% in the transitional zone formal dwellings (4-5 floors), about $13 \%$, in the center (mostly traditional dwelling), in an area of the Municipality $2.5 \%$, and about $2 \%$ in high flats (palace, > 6-7 floors), Currila zone ; beach zone; interferer transitional areas.

Fig.1. Spatial dynamics of population and urban constructions (developed by the authors)

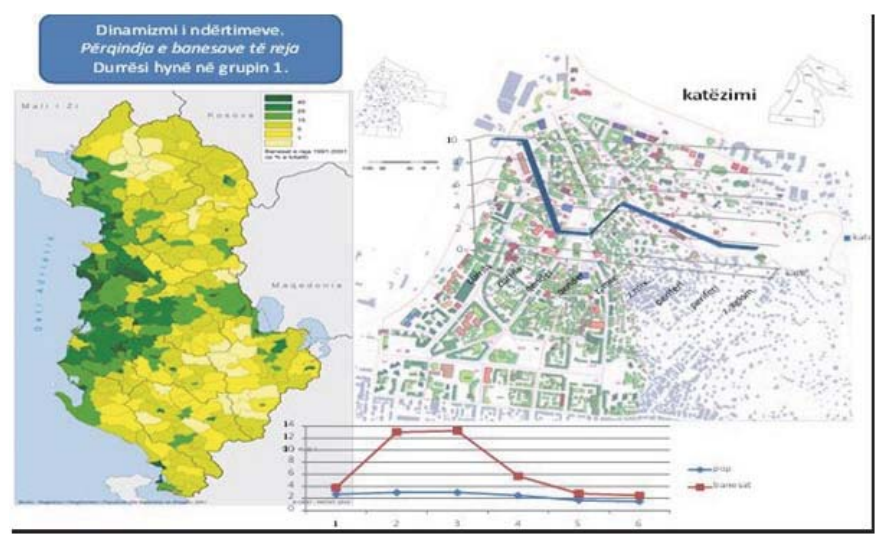

Regarding population density, they are divided into zones: high density and medium and high standard, in the historical center areas, city centers, shopping, Currila areas and tie areas on it, high density suburban satellite area, beach; with density medium and low zones like Shkozet and Këneta - marshes. Urban re-conception of projects be proposed according to: densification of buildings near the main road, increasing population density where housing renewal is possible. (5\% of traditional housing, the first years $1945,2 \%$ of monism period, etc., that can break down or renovated that's by weak material and structure, in the center, and increasing the coefficient of residential in the tourist area, where the annual housing coefficient to the beach area amounts only to $38 \%$ ).

In conclusion, from this point of view it can be said that the center has the capacity development through renewal and retraining, while the periphery through densification.

\section{Urbanized Processes Territorial and Functional Zoning}

Functional - territorial urban spaces before 1990 has had a strict functional zoning and homogenized in terms of urban space and the clear separation to stringent functional. Functional areas were divided into residential areas, historical museum, administrative, socio - cultural, tourist, economic, mostly in the suburbs with some infiltration of the old traditional industries.

After 1990 it can be found two 2 stages with distinctive features (up to 2006 and after 2006) on the causes, factors and geo-urban consequences. Young politico-economic factors reflected a territorial reassessment through recapitalization spatial urban center and periphery. This specific attributes based on the theories of urban zonal market economy: the economy of urban physical land and human assets, return on the trade center and senior services, creating and re logistics area, shipping and port ; retraining in the center through contemporary urbanization and its central functions; reorganization of the periphery through transfer of some urban functions and urban agriculture; further agglomerating the urban space through urban functions; union to homogenize urban several functional areas through urban sprawl, creating new urban peripheral areas as Beach zone; union perspective with satellite towns and cities (Shijak, Sukth, Shkozet etc.) and rural municipalities. As above, we have developed a functional zoning scheme (figure 2.)

Fig. 2. Functional zoning scheme geo-urban space city of Durres ( B. Draçi).

This overview knows some different part of territory, which everyone contains a special geographic-urban identity with stronger and functions typology. 


\begin{tabular}{|c|c|}
\hline The center & $\begin{array}{l}\text { 1. historical-monumental city zone: the center for services, markets, hotels, touristic, administrative, mostly } \\
\text { in the center } \\
\text { 2.politic-administrative urban zone } \\
\text { 3.CBD, business district center } \\
\text { 4. Harbor city: national and international range level. Zone to gateway function, receptions and transport } \\
\text { people and merchandise, nautical and services activities for the free time etc. } \\
\text { 5. Intensively residential city - Currila } \\
\text { 6. University area } \\
\text { 7. Social-cultural zone } \\
\text { 8. Hilly coast, the regional theme park. For touristic regional coordinated using }\end{array}$ \\
\hline Transitive zone & Consolidated city. Zone residential- services- mercantile function \\
\hline Periphery & $\begin{array}{l}\text { 1. Coastal resort town. area for summer vacation but should be strengthened with tourist services, } \\
\text { infrastructure and residential. } \\
\text { 2. Two urban zones: Shkozeti. In which will thaw in itself flats and small production units as family enterprise } \\
\text { level and.. } \\
\text { 3. Këneta: will develop low density housing and low cost as social housing. as a residential area should } \\
\text { recover in the sense urbanity, economic, social and environmental. } \\
\text { 4. Industrial City = Industrial and energetic park: this zones has been for the productive activities and now is } \\
\text { searching for a development profile, services, connection to Corridor } 8 \text { and other industrial areas, urban } \\
\text { community, and a public circulation by using old railway routes. In the area noticed the large occupation } \\
\text { illegal settlements. } \\
\text { 5. Fishing Port. }\end{array}$ \\
\hline $\begin{array}{l}\text { Extra urban and } \\
\text { agglomeration zone }\end{array}$ & $\begin{array}{l}\text { Areas with urban function and other cities/suburban communes without urban homogeneity like Shijak, } \\
\text { Sukth, Rashbull, etc. }\end{array}$ \\
\hline
\end{tabular}

\section{Central Area of Durres}

The area of the city center of Durres has a lump role as center -specific services and basic urban character, cultural and tourist center, the administrative seat of political presences, with fewer residential functions etc. Areas of central functions would include (see fig.2): the old center, the rest of the central functions of the CBD (Central Business District) Port, Currila zones; University area, the area of transport services in the front of Port. Old area constitutes 92.16 hectares or $2.04 \%$ of the Hall (7800 ha). Residential space with over 500 b/ha., occupies 74\%, including new Currila area. Functional typology based on historical assets, human and less physical assets: cultural sites, administrative, institutional, public landscaping, interior coastal tourism, port, center for public services etc. As new development is presented the CBD as well, an area built from the port area to train and bus terminal as commercial and logistic platform. That's by the needs to connect the port to the city by integrating it into life and contemporary developments. The platform includes the area shopping centers, hotels and bazaar spaces for cultural activity as well. ( picture?)

\section{Consolidated Transitional Zone}

In Western terms there are transitional urban areas, with mixed use space residential and commercial land placed between center and periphery. In general are flats/buildings of the period, especially after 1970 with the following features: standardized and urbanized area; has insertion palaces over 5 floors, but not dominant after 2000; with different socio- cultural constitution, but stabilized, formalized and social and cultural services, with a population of about 35 to 40 $\%$ of all; appear as " middle class " - (over $30 \%$ of average income ), without significant and dynamic changes, with a dominant functional profile residential area and small daily service; "average service of low -ranking " in terms of the theory of urban setting . (picture ?)

\section{Periphery Zone}

From point of socio - cultural aspect this is characterized as a condensation zone of arrived mostly rural population with environmental issues, urbanization, services and social-cultural character. It has different demographic, functional and morphological profile, with urban typology as follows:

a. Informal areas with populations over $40 \%$, average a 2 storey building, no social services at all dynamic indicators; no well urbanized in time requirements, with mostly primary infrastructure; without secondary infrastructure or weak infrastructure. 
b. Shkozeti areas, functions and morphology mixes. There are two urban areas, Shkozet and Këneta (marshland). The first, the placement in small apartment and production units (enterprises at household level), and the second place with low -density housing, but both will be characterized by low -cost buildings.

c. High density areas (beach zone), with secondary residences and apartment highly, with a seasonal population of up to $38 \%$ maximum, with good primary infrastructures.

Between this area and further development, emerging the core industrial zone, fishing port, urban agriculture, etc., with rapidly more spatial perspective but regionally, nationally and beyond radius.

\section{Agglomeration Area}

This outer space includes area with urban functions and processes without homogeneity urban. This includes mostly industry production, processing and services (light industry factories and food industry "fasson" factory lines and building materials, services, packaging, poultry, energy and industrial park etc.. In prospects in question, is the Durres metropolis?. Upon joining urban agglomeration and satellite towns as Shkozet, Sjijak, Sukth etc., and surroundings rurubanized municipalities to to resort urbanization (Rrashbull, Katund i Ri), the process moves toward metropolitan urban entity.

\section{Some Center- Periphery Indicators, in View of the Quality of Life}

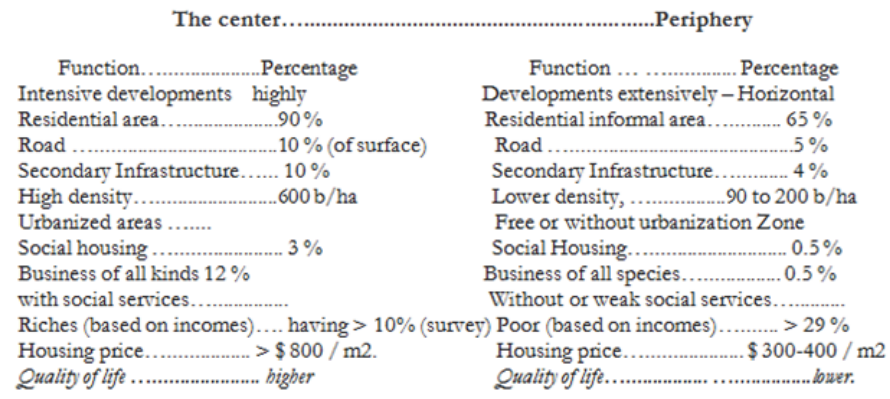

\section{References}

Durres Municipality, urban planning office and the office of Statistics.

Beaujeu-Garnier.J., Chabot, G., Urban Geography 1966

Fuga A. "The Fall of the City". Tirana 2010. and today's crisis is a crisis of urban centers, and not the suburbs. Interview 2011. Hall. P., Issues in Urban Society, 1978

Herbert T. David \& Colin J. Thomas. (1982). Urban geography. A first approach. London, New York. USA

Knox, P., Urban social geography, 1995

Institute of Statistics. INSTAT Albania.

Institute of Cultural Monuments. Tirana 2011

Xhafa S. Development of urban centers of Durres district, use of space and territorial regulation. Tirana 2011. (PhD) 